\title{
ANALISIS PERSEPSI PASIEN DALAM MEMUTUSKAN PEMANFAATAN INDEN RAWAT INAP KASUS BEDAH ELEKTIF RSI JEMURSARI SURABAYA
}

Analysis of Patient Perception to Make Bed Reservation to Be Hospitalized For Elective Surgical Cases

\author{
Dini Aftin Rahmadevi
}

Perhimpunan Sarjana dan Profesional Kesehatan Masyarakat Indonesia (Persakmi) Kabupaten Kediri, Indonesia

E-mail: drahmadevi@gmail.com

\begin{abstract}
RSI Jemursari Surabaya has a queueing system for hospitalize that had reservation for elective surgical cases, but there were some cancelled service during the last five months in 2016. Reservation of hospitalize system was implemented to optimize the service especially for elective surgical cases. This study was conducted to analyze the difference of patient's perception who going to be hospitalized for elective surgery purpose. This is a descriptive quantitative study using cross sectional approach for data collection. Simple random sampling technique was used to determine sample size to be studied. Sample criteria was patient aged 25 to 46 years old who domiciled in Surabaya. Data collected by questionnaire which given to 50 respondents. There were two types of respondent, patients that decided to cancel and patient that decided not to cancel the service. The statistical test of this study used Sample T Test with significancy 0.05. The perceptions of waiting time can determine the decision of the patients to be hospitalized for the case of elective surgical. The shorter period of waiting time ( $\leq 7$ days) would minimized the probability of patients from cancelling the indent for elective surgical. This study concluded that there were dissimilarity patient's perception regarding the waiting time of reservation for elective surgical cases.
\end{abstract}

Keywords: decision, elective surgery, hospitalize, perceptions, utilization

\section{ABSTRAK}

RSI Jemursari Surabaya memiliki sistem antrian yang berlaku untuk pasien inden rawat inap kasus bedah elektif, namun terdapat pembatalan oleh pasien selama lima bulan terakhir pada 2016. Sistem inden rawat inap kasus bedah elektif dilaksanakan untuk optimalisasi pelayanan rawat inap khususnya kasus bedah elektif. Penelitian ini dilakukan untuk menganalisis persepsi pasien yang melakukan inden rawat inap kasus bedah elektif. Jenis penelitian ini adalah deskriptif kuantitatif dengan desain cross sectional. Teknik pengambilan sampel dalam penelitian ini adalah simple random sampling. Kriteria responden penelitian ini adalah pasien berusia 25 tahun hingga 46 tahun yang berdomisili di Surabaya. Pengambilan data menggunakan instrumen berupa kuesioner yang diberikan kepada 50 orang responden. Responden dikelompokkan menjadi dua yaitu pasien yang mengambil keputusan batal dan tidak batal terhadap pemanfaatan inden rawat inap kasus bedah elektif. Uji statistik yang digunakan dalam penelitian ini adalah Uji T Sampel Bebas dengan nilai signifikansi 0,05. Persepsi pasien mengenai waktu tunggu dapat menentukan keputusan melakukan rawat inap kasus bedah elektif. Semakin cepat waktu tunggu ( $\leq 7$ hari) akan membuat pasien tidak membatalkan inden rawat inap bedah elektif. Kesimpulan dari penelitian ini adalah ada perbedaan persepsi pasien mengenai waktu tunggu inden rawat inap kasus bedah elektif.

Kata Kunci: bedah elektif, keputusan, pemanfaatan, persepsi, rawat inap

\section{PENDAHULUAN}

Masyarakat Indonesia mengalami perkembangan pola pikir tentang kesehatan. Perkembangan pola pikir masyarakat tersebut ditunjang dengan berbagai program jaminan kesehatan dari pemerintah. Perkembangan pola pikir mengenai kesehatan yang dimiliki masyarakat Indonesia lebih banyak mengarah pada kuratif. Pola pikir tersebut berdampak pada munculnya beberapa masalah pada pelayanan kesehatan, khususnya rumah sakit.

Rumah sakit memiliki fungsi salah satunya yaitu memelihara dan meningkatkan kesehatan perorangan melalui pelayanan kesehatan yang paripurna tingkat kedua dan ketiga sesuai dengan kebutuhan medis (Republik Indonesia, 2009). Berdasarkan Keputusan Menteri Kesehatan nomor 129 tahun 2008 tentang Standar Pelayanan Minimal Rumah Sakit, salah satu pelayanan yang harus dimiliki oleh rumah sakit adalah pelayanan rawat inap.

Rumah Sakit Islam (RSI) Jemursari Surabaya merupakan salah satu rumah sakit swasta yang memberikan pelayanan kesehatan kepada masyarakat Surabaya. RSI Jemursari Surabaya merupakan rumah sakit Tipe $B$ dengan beberapa pelayanan unggulan salah satunya adalah stroke 
center. Pihak RSI Jemursari Surabaya memberikan pelayanan kepada pasien dengan debitur pelayanan pribadi (umum), BPJS Kesehatan, BPJS Ketenagakerjaan, beberapa asuransi swasta serta perusahaan atau instansi yang memiliki kerja sama dengan RSI Jemursari Surabaya.

Kunjungan rawat inap RSI Jemursari Surabaya mengalami peningkatan terhitung sejak tahun 2014 Pihak RSI Jemursari Surabaya terus melakukan perbaikan untuk memberikan pelayanan yang lebih baik kepada masyarakat termasuk dalam pelayanan rawat inap. Salah satu kendala yang dimiliki oleh RSI Jemursari Surabaya adalah pelaksanaan pelayanan rawat inap kasus bedah elektif. Pihak RSI Jemursari Surabaya membuat upaya perbaikan pelayanan rawat inap kasus bedah elektif berupa sistem inden.

Inden rawat inap kasus bedah elektif dilaksanakan oleh pasien yang sudah mendapatkan surat pengantar masuk rumah sakit utamanya dari Poli Rawat Jalan. Pasien yang sudah mendapatkan surat pengantar mengurus administrasi di Tempat Pendaftaran Pasien Rawat Inap (TPPRI). Sistem inden rawat inap kasus bedah elektif di RSI Jemursari baru dilaksanakan secara efektif pada tahun 2016. Dalam pelaksanaannya, ada beberapa hal yang dianggap bermasalah oleh pasien. Masalah yang dirasakan pasien berdampak pada keputusan pemanfaatan inden rawat inap kasus bedah elektif. Masalah yang diangkat dalam penelitian ini adalah adanya pembatalan inden rawat inap kasus bedah elektif oleh pasien sebesar $21,40 \%$ selama tahun 2016.

Penelitian ini bertujuan untuk menganalisis persepsi pasien mengenai biaya, fasilitas, pelayanan dan waktu tunggu terhadap keputusan pemanfaatan inden rawat inap kasus bedah elektif di RSI Jemursari Surabaya. Faktor persepsi merupakan penilaian pasien yang dapat memengaruhi keputusan yang akan diambil terhadap pelayanan inden rawat inap kasus bedah elektif. Penelitian ini diharapkan dapat memberikan informasi tentang persepsi pasien terhadap pelayanan rawat inap khususnya kasus bedah elektif di RSI Jemursari Surabaya. Informasi yang dihasilkan dari penelitian ini diharapkan dapat digunakan sebagai masukan rumah sakit dalam melakukan perencanaan dan evaluasi pelayanan.

\section{METODE}

Penelitian ini dilakukan pada bulan November 2016 hingga Mei 2017. Penelitian ini merupakan penelitian observasional analitik dengan rancang bangun cross sectional. Penelitian dilakukan dengan cara mendatangi responden dari rumah ke rumah. Lokasi penelitian ini adalah di rumah responden di kota Surabaya.

Populasi penelitian ini adalah pasien yang melakukan inden rawat inap kasus bedah elektif di RSI Jemursari Surabaya terhitung mulai bulan Agustus hingga Desember 2016 dan termasuk dalam usia 25 hingga 46 tahun sebesar 96 orang. Besar sampel dalam penelitian ini adalah sebesar 50 pasien. Pengambilan sampel dilakukan dengan teknik simple random sampling.

Responden dalam penelitian ini adalah pasien yang termasuk dalam daftar inden rawat inap kasus bedah elektif baik yang mengambil keputusan pemanfaatan batal maupun tidak batal. Teknik analisis yang digunakan dalam pengolahan hasil penelitian ini adalah Uji T sampel bebas dengan nilai signifikans 0,05 . Instrumen yang digunakan dalam penelitian ini adalah kuesioner. Peneliti juga menggunakan data sekunder berupa Laporan Bulanan Inden Rawat Inap Kasus Bedah Elektif RSI Jemursari Surabaya.

\section{HASIL DAN PEMBAHASAN}

\section{Keputusan Pemanfaatan Inden Rawat Inap Kasus Bedah Elektif}

Seseorang akan membuat keputusan sesua dengan yang diinginkan (Kotler \& Armstrong, 2008) Dua hal yang akan berperan dalam menentukan keputusan seseorang yaitu pengaruh dari orang lain dan situasi yang tidak diinginkan. Keputusan responden terhadap pemanfaatan inden rawat inap kasus bedah elektif terbagi menjadi dua yaitu batal dan tidak batal.

Responden dari penelitian ini berjumlah 50 orang dengan kategori 42 orang responden yang mengambil keputusan pemanfaatan tidak batal dan 8 orang responden yang mengambil keputusan batal terhadap inden rawat inap kasus bedah elektif di RSI Jemursari Surabaya. Cara pengukuran yang digunakan untuk mengetahui keputusan pemanfaatan inden rawat inap kasus bedah elektif adalah membandingkan antara Laporan Bulanan Inden Rawat Inap Kasus Bedah Elektif RSI Jemursari Surabaya dengan jawaban responden tentang keputusan pemanfaatan inden rawat inap kasus bedah elektif. Laporan Bulanan Inden Rawat Inap Kasus Bedah Elektif berisi tentang daftar pasien yang telah mendapatkan pelayanan rawat inap, belum mendapatkan pelayanan rawat inap dan membatalkan rawat inap kasus bedah elektif di RSI Jemursari Surabaya.

Hasil penelitian menunjukkan bahwa terdapat beberapa ketidaksesuaian antara jawaban responden mengenai keputusan pemanfaatan inden rawat inap kasus bedah elektif dengan Laporan Bulanan Inden Rawat Inap Kasus Bedah Elektif RSI Jemursari Surabaya. Beberapa responden yang termasuk dalam pasien dengan keputusan pemanfaatan batal ternyata telah mendapatkan pelayanan rawat inap dan tindakan bedah elektif dari RSI Jemursari Surabaya. Keputusan pemanfaatan untuk batal atau tidak batal inden rawat inap kasus bedah elektif dapa dipengaruhi oleh beberapa faktor (Kotler \& Armstrong, 2008). Salah satu faktor yang berpengaruh adalah persepsi dari pasien terhadap rumah sakit. Keputusan dapat muncul dari beberapa alternatif yang ada (Setiadi, 2003). Responden memiliki beberapa hal yang menjadi pertimbangan dalam menentukan keputusan pemanfaatan inden rawat inap kasus bedah elektif di RSI Jemursari Surabaya. 
Tabel 1. Distribusi Persepsi Responden terhadap Biaya, Fasilitas, Pelayanan dan Waktu Tunggu dalam Memutuskan Pemanfaatan Inden Rawat Inap Kasus Bedah Elektif di RSI Jemursari Surabaya

\begin{tabular}{|c|c|c|c|c|c|}
\hline \multirow{3}{*}{ Persepsi } & \multicolumn{4}{|c|}{ Keputusan Responden } & \multirow{3}{*}{$p$} \\
\hline & \multicolumn{2}{|c|}{ Batal } & \multicolumn{2}{|c|}{ Tidak Batal } & \\
\hline & $\Sigma$ & $\%$ & $\Sigma$ & $\%$ & \\
\hline \multicolumn{6}{|l|}{ Biaya tambahan } \\
\hline Ada & 7 & 23,3 & 23 & 76,7 & 0,086 \\
\hline Tidak & 1 & 5 & 19 & 95 & \\
\hline \multicolumn{6}{|c|}{ Keterjangkauan Biaya Tambahan } \\
\hline Terjangkau & 7 & 25,9 & 20,0 & 74,1 & 0,322 \\
\hline Tidak Terjangkau & 0 & 0 & 3 & 100 & \\
\hline \multicolumn{6}{|l|}{ Biaya transportasi } \\
\hline Murah & 7 & 14,89 & 40 & 85,11 & 0,403 \\
\hline Mahal & 1 & 33,33 & 2 & 66,67 & \\
\hline \multicolumn{6}{|l|}{ Mekanisme pembayaran } \\
\hline Mudah & 8 & 16 & 42 & 84 & 1,000 \\
\hline Sulit & 0 & 0 & 0 & 0 & \\
\hline \multicolumn{6}{|l|}{ Kelengkapan } \\
\hline Lengkap & 8 & 16,6 & 42 & 84 & 1,000 \\
\hline Tidak Lengkap & 0 & 0 & 0 & 0 & \\
\hline \multicolumn{6}{|l|}{ Kenyamanan } \\
\hline Nyaman & 8 & 16,3 & 41 & 83,7 & 0,663 \\
\hline Tidak Nyaman & 0 & 0 & 1 & 100 & \\
\hline \multicolumn{6}{|l|}{ Pelayanan Dokter } \\
\hline Baik & 8 & 16,3 & 41 & 83,7 & 0,663 \\
\hline Tidak baik & 0 & 0 & 1 & 100 & \\
\hline \multicolumn{6}{|l|}{ Pelayanan Perawat } \\
\hline Baik & 8 & 17,1 & 39 & 82,9 & 0,440 \\
\hline Tidak baik & 0 & 0 & 3 & 100 & \\
\hline \multicolumn{6}{|c|}{ Pelayanan Tenaga Administrasi } \\
\hline Baik & 7 & 14,6 & 41 & 85,4 & 0,185 \\
\hline Tidak baik & 1 & 50 & 1 & 50 & \\
\hline \multicolumn{6}{|l|}{ Waktu Tunggu } \\
\hline Cepat & 0 & 0 & 32 & 100 & 0,001 \\
\hline Lama & 8 & 44,4 & 10 & 55,6 & \\
\hline \multicolumn{6}{|l|}{ Lama Waktu Tunggu } \\
\hline \multirow{3}{*}{$\begin{array}{l}\leq 7 \text { hari } \\
8-14 \text { hari } \\
14 \text { hari }<\end{array}$} & 1 & 3,2 & 30 & 96,8 & \multirow{3}{*}{0,001} \\
\hline & 1 & 16,7 & 5 & 83,3 & \\
\hline & 6 & 46,2 & 7 & 53,8 & \\
\hline
\end{tabular}

\section{Persepsi Biaya}

Responden merupakan pasien yang melakukan inden rawat inap kasus bedah elektif adalah pasien dengan debitur pelayanan BPJS, asuransi swasta atau instansi yang bekerja sama dengan RSI Jemursari Surabaya. Responden dalam penelitian ini adalah 47 orang pasien dengan debitur pelayanan BPJS Kesehatan dan 3 orang pasien dengan debitur pelayanan asuransi swasta atau instansi yang menjalin kerja sama dengan rumah sakit. Indikator yang digunakan dalam melihat persepsi biaya atau pembayaran di rumah sakit adalah adanya biaya tambahan, keterjangkauan biaya tambahan, biaya transportasi dan mekanisme pembayaran yang ada di rumah sakit.

Hampir seluruh pasien yang termasuk dalam daftar inden pasien rawat inap kasus bedah elektif di RSI Jemursari Surabaya adalah pasien BPJS Kesehatan. Tidak ada pasien yang mendaftar inden rawat inap kasus bedah elektif dengan pembayaran mandiri atau disebut juga pasien umum (tanpa debitur pelayanan pihak ketiga). Hal ini juga dibenarkan oleh pihak RSI Jemursari Surabaya. Pasien umum tidak akan masuk dalam daftar antrian inden.

Setiap peserta berhak menerima manfaat BPJS Kesehatan, salah satunya adalah tindakan medis 
operatif serta rawat inap sesuai dengan indikasi (Kementerian Kesehatan Republik Indonesia, 2011). Responden mengaku bahwa penggunaan jaminan BPJS Kesehatan, asuransi swasta atau instansi yang bekerja sama dengan pihak rumah sakit, tidak merasakan perbedaan pelayanan antara dirinya dengan pasien umum.

Berdasarkan Tabel 1 menunjukkan bahwa ada biaya tambahan yang dikeluarkan meskipun perawatan sudah dibiayai oleh pihak ketiga yaitu BPJS Kesehatan, asuransi swasta atau instansi yang bekerja sama dengan RSI Jemursari Surabaya. Seluruh responden yang mengeluarkan biaya tambahan menyatakan bahwa biaya tambahan yang dikeluarkan termasuk dalam kategori terjangkau. Hasil penelitian menunjukkan bahwa tidak ada perbedaan persepsi dari responden yang mengambil keputusan pemanfaatan batal maupun tidak batal terhadap inden rawat inap kasus bedah elektif di RSI Jemursari Surabaya $(p>0,05)$.

Hampir seluruh responden menyatakan bahwa ada biaya tambahan untuk mendapatkan pelayanan di RSI Jemursari Surabaya, namun biaya tambahan yang dikeluarkan oleh responden masuk dalam kategori terjangkau. Responden yang menyatakan biaya tambahan tidak terjangkau adalah responden dengan debitur pelayanan asuransi swasta. Pihak asuransi swasta hanya memberikan jaminan pelayanan bedah elektif sebesar $50 \%$ dari total biaya bedah elektif yang diterima oleh pasien.

Seorang pasien harus mengeluarkan biaya transportasi dalam mendapatkan pelayanan (perawatan) rawat inap di RSI Jemursari Surabaya. Hasil penelitian menunjukkan bahwa tidak ada perbedaan persepsi biaya transportasi yang dikeluarkan responden baik yang mengambil keputusan pemanfaatan batal maupun tidak batal dalam pemanfaatan inden rawat inap kasus bedah elektif di RSI Jemursari Surabaya $(p>0,05)$. Sebagian besar responden menyatakan biaya transportasi yang dikeluarkan termasuk dalam kategori murah. Biaya transportasi dianggap murah oleh hampir seluruh responden karena memiliki kendaraan pribadi, sehingga tidak memerlukan angkutan umum menuju RSI Jemursari Surabaya.

Responden yang menyatakan biaya transportasi masuk ke dalam kategori mahal karena memiliki keterbatasan mengenai kendaraan pribadi. Responden tersebut harus menggunakan angkutan umum apabila menuju RSI Jemursari Surabaya. Domisili responden tidak dilalui oleh kendaraan umum, sehingga angkutan umum yang digunakan adalah taksi dengan biaya yang termasuk mahal.

Berdasarkan hasil penelitian, variabel mekanisme pembayaran menunjukkan tidak ada perbedaan persepsi mekanisme pembayaran rawat inap di RSI Jemursari Surabaya baik menurut responden yang mengambil keputusan pemanfaatan batal atau tidak batal terhadap inden rawat inap kasus bedah elektif $(p>0,05)$. Seluruh responden baik yang mengambil keputusan pemanfaatan batal atau tidak batal terhadap inden rawat inap kasus bedah elektif menyatakan bahwa mekanisme pembayaran dengan menggunakan debitur pelayanan BPJS Kesehatan maupun asuransi swasta atau instansi yang kerja sama termasuk dalam kategori mudah. Mekanisme pembayaran dengan BPJS Kesehatan maupun asuransi swasta atau instansi kerja sama sudah memiliki alur yang jelas dari pihak ketiga, sehingga pelaksanaannya pun juga mudah.

Menurut pengakuan responden dengan debitur pelayanan BPJS Kesehatan, mekanisme pembayaran pelayanan rawat inap sudah baik meskipun responden terlambat dalam membayar iuran bulanan. Bagi responden yang mengalami keterlambatan pembayaran iuran, tenaga administras akan memberikan formulir persetujuan penyelesaian pembayaran (denda dan keterlambatan iuran) dalam tempo 2x24 jam. Pihak keluarga responden wajib menyelesaikan permasalahan keterlambatan pembayaran di kantor BPJS Kesehatan. Seseorang akan menggunakan BPJS Kesehatan lagi (berulang) apabila seseorang tersebut merasakan kepuasan (Vianti, 2016).

\section{Persepsi Fasilitas}

Fasilitas merupakan salah satu hal yang memengaruhi seseorang dalam memilih tempat pembelian (Kotler \& Armstrong, 2008). Dalam menilai persepsi terhadap fasilitas yang ada di rumah sakit digunakan dua indikator yaitu kelengkapan dan kenyamanan. Persepsi kenyamanan dan kelengkapan fasilitas yang baik dapat berpengaruh terhadap keputusan pasien.

Pada variabel persepsi kelengkapan fasilitas, menunjukkan bahwa tidak ada perbedaan perseps kelengkapan fasilitas yang dimiliki RSI Jemursari Surabaya menurut responden yang mengambil keputusan pemanfaatan batal dan tidak batal inden rawat inap kasus bedah elektif $(p>0,05)$. Berdasarkan Tabel 1 dapat dilihat bahwa seluruh responden memiliki persepsi bahwa fasilitas yang ada RSI Jemursari Surabaya termasuk dalam kategori lengkap. Bagi responden yang akhirnya memutuskan untuk membatalkan pemanfaatan inden rawat inap juga memiliki persepsi bahwa RSI Jemursari Surabaya memiliki fasilitas yang lengkap. Kelengkapan fasilitas yang baik dapat memenuhi kebutuhan pasien dalam pelayanan (Anggraheni, 2012).

Pada variabel persepsi responden terhadap fasilitas yang ada di rumah sakit, yang diukur adalah kelengkapan dan kenyamanan ruang tunggu pengambilan obat, ruang administrasi, ruang operasi dan ruang rawat inap. Fasilitas merupakan salah satu faktor yang menunjang pertimbangan seseorang untuk memilih pelayanan di rumah sakit (Mongkaren, 2013). Hasil penelitian menunjukkan bahwa tidak ada perbedaan persepsi kenyamanan fasilitas menurut responden yang membatalkan maupun yang tidak membatalkan inden rawat inap kasus bedah elektif di RSI Jemursari Surabaya $(p>0,05)$. Hampir seluruh responden menyatakan bahwa fasilitas yang ada di RSI Jemursari masuk dalam kategori nyaman.

Ada satu responden dengan keputusan pemanfaatan tidak batal terhadap inden rawat inap kasus bedah elektif menyatakan bahwa fasilitas di RSI Jemursari Surabaya masuk dalam kategori tidak nyaman. Kenyamanan ruangan dan fasilitas dapat memengaruhi kepuasan pengguna jasa pelayanan 
kesehatan (Muninjaya, 2004). Responden yang menyatakan ketidaknyamanan dengan fasilitas yang ada di RSI Jemursari Surabaya karena memiliki pengalaman mengenai pengambilan obat. Suasana yang ramai dengan tempat duduk yang terbatas membuat responden menunggu pengambilan obat dengan berdiri. Responden mengaku harus menunggu (antri) lagi di dalam ruang operasi.

Fasilitas dan lingkungan rumah sakit yang nyaman adalah salah satu layanan yang diharapkan oleh pasien. Suatu pelayanan dikatakan bermutu apabila telah memenuhi harapan pelanggan (Supriyanto \& Wulandari, 2011). Dalam penelitian ini hampir seluruh responden menyatakan bahwa fasilitas yang ada di RSI Jemursari Surabaya termasuk dalam kategori nyaman, namun tidak diukur mengenai harapan responden tentang fasilitas yang ada di rumah sakit sehingga tidak dapat dikatakan bahwa fasilitas yang ada sudah sesuai dengan harapan responden.

\section{Persepsi Pelayanan}

Indikator yang digunakan untuk menilai persepsi responden tentang pelayanan yang ada di RSI Jemursari Surabaya adalah ketanggapan, kehandalan dan keramahan dari petugas. Petugas yang dimaksud adalah yang berhubungan dengan pelayanan rawat inap dokter, perawat dan tenaga administrasi. Berdasarkan penilaian dari tiga hal tersebut, maka pelayanan akan dikategorikan menjadi dua yaitu baik dan tidak baik.

Persepsi pelayanan yang diberikan oleh dokter berdasarkan Tabel 1, masuk dalam kategori baik. Hasil penelitian menunjukkan bahwa tidak ada perbedaan persepsi pelayanan yang diberikan oleh dokter menurut responden yang membatalkan maupun tidak membatalkan inden rawat inap kasus bedah elektif di RSI Jemursari Surabaya $(p>0,05)$. Satu orang responden menyatakan bahwa pelayanan dari dokter tidak baik karena sikap dokter yang tidak ramah. Dokter dianggap tidak menjelaskan secara lengkap dan cenderung meremehkan daya tangkap dari responden lain.

Sebagian besar responden memiliki persepsi pelayanan yang diberikan oleh perawat masuk dalam kategori baik. Hasil penelitian menunjukkan bahwa tidak ada perbedaan persepsi pelayanan yang diberikan oleh perawat menurut responden yang mengambil keputusan pemanfaatan batal maupun tidak batal terhadap inden rawat inap kasus bedah elektif di RSI Jemursari Surabaya $(p>0,05)$. Responden yang menyampaikan tentang kurang baiknya pelayanan perawat, karena responden yang bersangkutan diberikan pelayanan oleh perawat magang tanpa didampingi oleh perawat tetap rumah sakit. Responden merasa kemampuan perawat magang dapat membahayakan keselamatannya.

Pada variabel persepsi pelayanan yang diberikan oleh tenaga administrasi, berdasarkan Tabel 1 dapat dilihat bahwa sebagian besar responden memiliki persepsi pelayanan yang diberikan oleh tenaga administrasi masuk dalam kategori baik. Hasil penelitian menunjukkan bahwa tidak ada perbedaan persepsi pelayanan yang diberikan oleh tenaga administrasi menurut responden yang mengambil keputusan pemanfaatan batal dan tidak batal terhadap inden rawat inap kasus bedah elektif di RS Jemursari Surabaya $(p>0,05)$. Dua orang responden yang merasa pelayanan oleh tenaga administrasi tidak baik karena tenaga administrasi dianggap tidak tanggap. Tenaga administrasi tidak memberikan kepastian mengenai waktu rawat inap kasus bedah elektif yang akan diterima pasien.

Sebagian besar responden yang mengambil keputusan pemanfaatan batal maupun tidak batal terhadap inden rawat inap kasus bedah elektif memiliki persepsi pelayanan (yang diberikan rumah sakit) termasuk dalam kategori baik. Persepsi yang baik terhadap pelayanan yang diberikan rumah sakit dapat mendatangkan keuntungan pembelian (kembali) di masa yang akan datang (Sutisna, 2011). Persepsi responden yang tidak baik terhadap pelayanan dokter, perawat serta tenaga administrasi dalam memutuskan pemanfaatan inden rawat inap kasus bedah elektif di RSI Jemursari dapat membuat pasien tidak melakukan pemanfaatan kembali pelayanan yang ada di RSI Jemursari Surabaya.

Menurut Moenir (2002), pelayanan adalah suatu kegiatan yang bertujuan untuk menyiapkan atau mengurus hal yang diperlukan oleh orang lain. Responden dengan debitur pelayanan BPJS Kesehatan maupun asuransi swasta atau instansi yang menjalin kerja sama dengan RSI Jemursari Surabaya merasa tidak ada perbedaan pelayanan selama dirawat. Responden sebagian besar merasa bahwa pelayanan dokter, perawat dan tenaga administrasi telah ramah, handal dan tanggap tanpa membedakan status debitur pembayaran yang digunakan oleh pasien.

\section{Persepsi Waktu Tunggu}

Pasien yang melakukan pendaftaran inden rawat inap kasus bedah elektif di RSI Jemursari Surabaya akan diberikan penjelasan untuk menunggu kabar dari rumah sakit. Penjelasan akan diterima pasien dari petugas administrasi yang ada di TPPRI. Persepsi responden terhadap waktu tunggu diukur melalui kecepatan antrian yang akan dikategorikan menjadi dua yaitu lama dan cepat.

Pada variabel persepsi waktu tunggu, berdasarkan Tabel 1 menunjukkan bahwa persepsi waktu tunggu seluruh responden yang mengambil keputusan pemanfaatan batal, menyatakan bahwa waktu tunggu inden rawat inap kasus bedah elektif termasuk dalam kategori lama. Seluruh responden yang mengambil keputusan pemanfaatan tidak batal menyatakan bahwa waktu tunggu inden rawat inap kasus bedah elektif masuk dalam kategori cepat. Hasil penelitian menunjukkan bahwa ada perbedaan persepsi waktu tunggu menurut responden yang mengambil keputusan pemanfaatan batal dan tidak batal terhadap inden rawat inap kasus bedah elektif di RSI Jemursari Surabaya $(p<0,05)$.

Seseorang akan merasakan kepuasan apabila mendapatkan hal yang diinginkan (Lovenia, 2012). Seluruh responden yang mengambil keputusan pemanfaatan batal memiliki persepsi bahwa waktu tunggu inden rawat inap kasus bedah elektif termasuk dalam kategori lama. Seluruh responden yang mengambil keputusan pemanfaatan tidak batal 
memiliki persepsi bahwa waktu tunggu inden rawat inap kasus bedah elektif termasuk dalam kategori cepat. Bagi responden yang mengambil keputusan pemanfaatan batal terhadap inden rawat inap kasus bedah elektif, sebagian menganggap bahwa dirinya sudah sembuh dan tidak perlu untuk mendapatkan pelayanan rawat inap kasus bedah elektif di RSI Jemursari Surabaya. Bagi responden yang mengambil keputusan pemanfaatan tidak batal menyatakan lebih memilih untuk mendapatkan perawatan rawat inap serta tindakan bedah elektif di rumah sakit lain. Salah satu cara untuk meningkatkan kepuasan pelanggan adalah tidak membiarkan pelanggan menunggu terlalu lama (Foster, 2000).

Berdasarkan hasil penelitian menunjukkan bahwa sebanyak 31 orang responden menyatakan waktu tunggu antrian inden rawat inap kasus bedah elektif termasuk dalam kategori $\leq 7$ hari. Sebesar $96,8 \%$ responden yang menyatakan lama waktu tunggu termasuk dalam kategori $\leq 7$ hari, mengambil keputusan untuk tidak batal memanfaatkan inden rawat inap kasus bedah elektifnya. Responden yang mengambil keputusan untuk batal memanfaatkan inden rawat inap kasus bedah elektif di RSI Jemursari Surabaya sebagian besar menyatakan telah menunggu lebih dari 14 hari. Responden yang termasuk dalam kategori ketiga mengaku telah menunggu lebih dari satu bulan untuk mendapatkan pelayanan di RSI Jemursari Surabaya.

Tidak ada acuan untuk menyatakan lama atau cepat waktu antrian yang dirasakan responden. Lama dan cepat waktu tunggu inden adalah sesuai dengan persepsi responden melihat kebutuhan dan tingkat kegawatan yang dirasakan oleh responden. Pihak rumah sakit mengaku belum menetapkan kategori lama waktu tunggu yang dapat dijadikan acuan untuk menilai waktu tunggu inden. Proses pengambilan keputusan memang tidak selalu berakhir pada transaksi pembelian (Tjiptono, 2006).

\section{SIMPULAN}

Berdasarkan hasil penelitian, maka dapat ditarik kesimpulan bahwa ada perbedaan persepsi mengenai waktu tunggu inden rawat inap kasus bedah elektif di RSI Jemursari Surabaya. Responden yang mengambil keputusan pemanfaatan batal, memiliki persepsi bahwa waktu tunggu inden rawat inap termasuk dalam kategori lama sedangkan responden yang mengambil keputusan pemanfaatan tidak batal memiliki persepsi waktu tunggu inden termasuk dalam kategori cepat. Persepsi pasien mengenai waktu tunggu dapat menentukan keputusan melakukan rawat inap kasus bedah elektif. Semakin cepat waktu tunggu ( $\leq 7$ hari) akan membuat pasien tidak membatalkan inden rawat inap kasus bedah elektif. Pihak manajemen rumah sakit perlu menyediakan penilaian kepuasan pasien tentang sistem inden rawat inap kasus bedah elektif sehingga dapat digunakan sebagai evaluasi dan perencanaan sistem inden rawat inap yang lebih baik.

\section{DAFTAR PUSTAKA}

Anggraheni, N. 2012. Faktor-faktor yang Memengaruhi Pengambilan Keputusan Masyarakat untuk Memilih Jasa Pelayanan Kesehatan di Rumah Sakit PKU Muhammadiyah Simo Kabupaten Boyolali. Skripsi. Surakarta: Universitas Muhammadiyah Surakarta.

Dewi, A. 2015. Hubungan Waktu Tunggu Pendaftaran dengan Kepuasan Pasien di Tempat Pendaftaran Pasien Rawat Jalan (TPPRJ) RSUD Sukoharjo. Skripsi. Surakarta: Universitas Muhammadiyah Surakarta.

Foster, T. 2000. 101 Cara Meningkatkan Kepuasan Pelanggan. Jakarta: Elex Media Computindo Kelompok Gramedia.

Kementerian Kesehatan Republik Indonesia, 2008. Keputusan Menteri Kesehatan nomor 129 tahun 2008 tentang Standar Pelayanan Minimal Rumah Sakit. Jakarta: Kementerian Kesehatan Republik Indonesia.

Kementerian Kesehatan Republik Indonesia, 2011. Buku Pegangan Sosialisasi JKN dan SJSN Jakarta: Kementerian Kesehatan Republik Indonesia.

Kotler, P. \& Armstrong, G. 2008. Prinsip-Prinsip Pemasaran. Jakarta: Erlangga.

Lovenia, C. 2012. Analisis Pengaruh Kualitas Pelayanan terhadap Kepuasan Nasabah. Skripsi. Semarang: Universitas Diponegoro.

Moenir, A. 2002. Manajemen Pelayanan Umum di Indonesia. Jakarta: Bumi Aksara.

Mongkaren, S. 2013. Fasilitas dan Kualitas Pelayanan Pengaruhnya terhadap Kepuasan Pengguna Jasa Rumah Sakit Advent Manado. Jurnal EMBA, 1(4), pp. 492-503.

Muninjaya, A. 2004. Manajemen Kesehatan. Jakarta: EGC.

Republik Indonesia. 2009. Undang-Undang Nomor 44 Tahun 2009 tentang Rumah Sakit. Jakarta: Republik Indonesia.

Setiadi, N.J. 2003. Perilaku Konsumen. Jakarta Kencana.

Supriyanto, S. \& Wulandari, R.D. 2011. Manajemen Mutu Pelayanan Kesehatan. Surabaya: Pohon Cahaya.

Sutisna. 2011. Perilaku Konsumen dan Komunikasi Pemasaran. Bandung: Remaja Rosdakarya Offset.

Tjiptono, F. 2006. Pemasaran Jasa. Malang: Bayu Publishing.

Vianti, N.R. 2016. Analisis Kepuasan Pasien BPJS (Badan Penyelenggara Jaminan Sosial) terhadap Pelayanan Kesehatan di Instalasi Rawat Inap (IRI) bangsal Dahlia RS UD Ungaran. Skripsi. Semarang: Fakultas IImu Keolahragaan. 